\title{
The interrelationship between human resource management and corporate strategy
}

\author{
R. Abratt \\ Graduate School of Business Administration, University of the Witwatersrand, Johannesburg
}

\begin{abstract}
The involvement of personnel executives in the strategic planning of the enterprise is a controversial issue. Personnel has been considered a staff function which deals with day-to-day administration issues and as such has often been regarded with some contempt by the top management team. Concomitantly many firms are viewing the personnel function in an entirely different light; it now participates in the decision making of the company. The objectives of this paper are two fold: firstly to find a link between corporate strategy and human resource management and secondly, to find out whether personnel managers of quoted South African companies participate in corporate strategy formation. The company comprises of a number of varying dimensions and systems. Every organizational dimension and system must be consistent, not only with the strategy, but also with every other organizational dimension and system. The personnel department is often excluded from the corporate planning process. This exclusion represents a high cost to the total system due to less than optimum usage of an organization's human resources. This paper discusses the need for planning by management with particular reference to manpower planning in relation to corporate planning.

S. Afr. J. Bus. Mgmt. 1983, 14: 53- 59
\end{abstract}

Hierdie artikel handel eerstens oor die verband tussen kor. poratiewe strategie en die bestuur van menslike hulpbronne en tweedens, om te bepaal tot watter mate personeelbestuurders van genoteerde maatskappye in korporatiewe strategie formulering betrokke is. Die bevindinge toon dat personeeldepartemente nie deel het aan die korporatiewe proses nie. Die implikasies hiervan word bespreek.

S.Afr. Tydskr. Bedryfsı. 1983, 14: 53-59

\section{Introduction}

The involvement of Personnel in the Strategic Planning of the enterprise is a controversial issue. Personnel has long been considered a service function which deals primarily with day-to-day administration issues and as such has often been regarded with some contempt by the top management team. In many instances this may well have been justifiable, although there does exist a body of literature which is increasingly emphasizing the 'strategic' nature of human resource management. Concomitantly many firms are viewing the Personnel or Human Resource Manager in an entirely different light; he now participates actively in the decision-making of the company. The fact that Personnel management is now becoming known as Human Resource Management is indicative of the change in thinking that is taking place.

According to Ackoff,

'wisdom is the ability to see the long-run consequences of current actions, the willingness to sacrifice short-run gains for longer long-run benefit, and the ability to control what is controllable and not fret over what is not. Therefore the essence of wisdom is concern with the future and of effective ways of bringing it about. It is an instrument that is used by the wise, but not by the wise alone. When conducted by lesser men it often becomes an irrelevant ritual that produces short-run peace of mind, but not the future that is longed for.'

An organization must plan for the future if its objectives are to be realised and it is through the process of planning that corporate objectives are transmitted throughout the entire organization. Decision-making within the organization is based on firmly established objectives. If this is not the case, then 'decisions become random and the organization becomes blurred and eventually unable to survive.'

The objectives of this paper are twofold:

- to find a link between corporate strategy and human resource management.

- to find out whether personnel managers of quoted South African companies participate in corporate strategy formation.

Thus, this paper is divided into two sections, a theoretical section and a survey of sixty companies listed on the Johannesburg Stock Exchange. 


\section{The med for ploming}

Since today's society is dynamic, the future of the organization is uncertain and in order to hedge against uncertainty, organizations must formulate plans to adapt to change. The planning process will identify the needs of the future as well as the weaknesses, deficiencies and strengths in the present organizational structure. It is through planning that complex organizations reduce ambiguity and uncertainty by providing standards against which behaviour can be measured in achieving corporate objectives.

The organization comprises a number of varying dimensions and systems. Every organizational dimension and system must be consistent, not only with the strategy, but also with every other organizational dimension and system.

'All the dimensions, such as structure, reward systems and resource allocation processess must constitute an internally consistent organizational form."

Each dimension of management an integrity of its own and if the organization is to function effectively, the component dimensions of the management system must be compatibie. Every aspect of a managerial system is related to every other part and interacts with it. "It is important that the organic integrity of each system must be maintained." Such will not be the case where certain components of managerial systems are not included in the formulation of overall corporate goals and objectives, and the strategy to be used in achieving such goals and objectives. The personnel department is often excluded from the corporate planning process. This exclusion represents a high cost to the total sytrem due to less than optimum usage of an organization's human resources. As a result of such frequent exclusion of personnel executives from the corporate planning process, planning for the most effective use of human resources is, at best, haphazard and ad hoc. If this trend continues, personnel executives will find their position becoming continually weaker with regard to the total corporate system and the personnel function is in danger of being relegated to that of a technician's job or simply actministering wages and health and safety programmes.

The need for planning is usually determined by top corporate executives with final authorization resting with the general manager or chief executive officer of the organizanon. There appear to be sound reasons for authorizing plans at this level.

'If everyone in the organization were allowed to plan independently, considerable duplication of efforts, as well as conflicts between departments would occur."

A plan is simply a predetermined course of action. The planning process is:

the specification of the means necessary to achicve prescribed ends, before action toward the ends takes place. ${ }^{\prime}$

Once objectives have been stated four elements envolve in the planning process. They are:

- An evaluation oi present conditions which should identify areas where change is needed or will eventuare, even without planning.

- A time dimension which encompasses both short-run and long-run ptans.

- Data collection. This requires that a judgment(s) be made regarding the quality of data.

- A degree of importance should be attached to each plan and they shouid then be listed in rank order of priority.

If planning is to be realistic, use must be made of the information contained in staff departments. In any planning process, the head of each department must formulate plans in relation to the specific department, participate in the formulation of company-wide plans and assist other departments in formulating their plans. If any of these points are missing in the corporate planning process, the plans do not represent the entire company, but only segments thereof. It is the responsibility of top management to ensure that the planning process is co-ordinated.

Top management has a responsbility to optimize the total organization. Personnel executives are responsible for maximizing human resource utilization in relation to the attainment of the organization's goals, and this should place them in an important position relative to top management. Even though general managers realize that their most important and frequent problems are with people, they are often reluctant to utilize the personnel department in the search for and formulation of solutions. Perhaps one of the major reasons behind this reluctance is that general managets feel more secure 'doing it themselves'. In short, they lack faith in personnel's ability to supply accurate information and assistance in this area. Is such a lack of faith justified? In a number of cases it is; for it has been noted that personnel specialists are in many cases merely technicians who are not accustomed to thinking in terms of the entire organization. Due to their limited outlook, personnel executives have been overshadowed by consultants, or other organizational departments. Since personnel departments have been lax in projecting the future organization, evaluating management and developing people with potential to fit into the future organization, they have lost many important functions to other departments and/or units. Unless such deficiencies are corrected, petsonnel departments will forfeit everything of major significance to corporate planning units.

The cost of not fully utilizing the information found in the typical personnel department can only be hypothesized. However, since effective organization plans must deal with human resource requirements, non-use of any information in this area will, inevitably, be detrimental to the planning process and costly to the organization. If personnel executives are not integrated into the planning process, most, if not all, the available information will be lost to planners. Another disadvantage resulting from less than full usage of personnel departments is illustrated by the scarcity of specialized and skilled employees. Since such scarcity is tikeby to worsen with the increasing complexity of industry, the personnel department should be seen as a major factor influencing the planning and utilization of this scarce resource. In addition, personnel departments generally have access to the data and econometric models that can be used to level out the peaks and troughs of production in order to provide more stable employment and to effect various economies by such action. $W$ ithout making full and effective use of the information held by the personnel department, management may find itself planning to solve problems whish may in fact only be symptoms of problems;

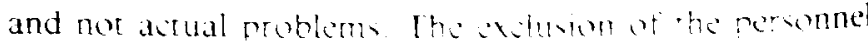


department may be detrimental to the operation of the planning process. Personnel has a number of communication channels through which information concerning change can be transmitted to the firm's human resources, thereby reducing the resistance to change inherent in any organization. In addition, the personnel department should be instrumental in the training of managers in the use of personalized communication in order to overcome the barriers to change. It should be noted that not every personnel department contains the information and tools necessary for helping management to plan for and initiate change through corporate objectives and strategies. Such information and tools must, however, be located somewhere in the organization if plans are to be formulated and successfully implemented. The personnel department appears to be the logical place to hold such information tools.

Future personnel managers will have to be closely associated with upper management. This can be accomplished by personnel specialists demonstrating their proficiency in assisting with problems in the human resources area and by taking responsibility for the decisions that are made. Through such close interaction personnel executives can make the general manager more conscious of communication systems and their effect on the organization. They can also attempt to design an organization that fits the company's human resources rather than merely 'accepting the organizational structure as it is and attempting to mould human resources around it. ${ }^{9}$ They will, furthermore, have to demonstrate to the line that the absence of the personnel function equals 'management by crisis,' and that it is better to be in a position where you can predict problems and prevent them from occurring. Finally, personnel executives must be in a position to demonstrate to top management the importance of the personnel function at all times. This importance must be demonstrated in relation to organizational profit and survival. This means that the personnel practitioner must learn the business that he/she is in. They must become expert in marketing, manufacturing and administration and must make an effort to learn about business and profit; and be able to talk with the accountants and financial directors of the organization in money terms. In short, the personnel practitioner must become a businessman who happens to be in personnel. It is only by improving the way in which they practice and by enhancing their status in the organization that personnel departments and practitioners will be able to gain and hold an integral part of the organizational planning process.

'Human resources planning can act as a catalyst and an operating mechanism to accelerate the building of an effective work force. Where this is accomplished, people are energized and committed and become the most powerful fundamental corporate competitive resource of all'. ${ }^{10}$

It would appear that effective human resource management is a pre-requisite for effective strategic management. Critical problems in the corporate management of personnel, such as the place of human resource management in corporate decision-making; the role of personnel staff and a lack of sufficient human resource management 'knowhow' at top management levels, remain largely unresolved. It is important for planners to recognize the 'dual nature' of planning. Planners may think only of the formal economic and physical resources facet when they develop a programme; but the human resources side is present at all times, as well.

'If planners were able to anticipate how various types of reporting, budgeting and operating procedures affect behaviour, they would then be able to plan and implement their plans with greater skill and sophistication."

\section{Manpower planning and corporate strategy}

Included among the objectives of personnel within the scope of corporate plans are:

- staffing;

- information and motivation of people within the organization;

- integration and co-ordination of personnel plans and programmes;

- contribution to improved communication and cooperation on the basis of more open labour relations;

- industrial relations;

- training and development;

- manpower planning;

- social matters;

- the effects of economic and political forces;

- the provision of links between personnel plans and the remainder of the corporate plans.

Since one of the major aims of personnel planning is the realisation of an optimum staffing within the scope of corporate plans, it would be appropriate to examine the contribution of manpower planning to the overall organizational/corporate plan(s) and strategies. ${ }^{12}$

'Manpower planning is a process which translates corporate objectives and operational needs and plans into future requirements and provides plans to fulfil these requirements through the efficient utilization of available manpower. Fundamental to manpower planning is the need for linkage and integration with other functions of the corporation; including economic and market forecasting, research and development planning and investment and systems planning. ${ }^{13}$

The formulation of organizational objectives and plans and manpower planning are interdependent at all organizational levels. This interdependence is particularly apparent for long-range planning. This fundamental objective of manpower planning and programming is to provide the organization with the personnel to perform the activities that will achieve organizational goals. Consequently, objectives and plans at all levels of the organization provide the basis for defining manpower requirements. Manpower data (i.e. the availability of specific skills and numbers of people) can be crucial inputs into the planning process. The availability of the needed manpower may determine whether a specific project can be undertaken. In other instances, there are significant manpower implications for proposed programmes such as mergers and acquisitions.

In an economic organization, manpower, like materials and facilities, should be considered as an investment alternative subject to similar cost, return, allocation and control considerations given to other resources. Thus efficien- 
cy and effectiveness enter the picture in terms of minimum cost and effective utilization of manpower resources in order to obtain an acceptable return on invested capital. Intimate knowledge of organizational plans and participation in the planning process can enhance both efficiency and and effectiveness. Close attention to the determination of manpower requirements and programming in terms of quality of skills, their numbers and cost can yield significant returns in terms of investment and utilization of human resources.

If manpower planning is not integrated with the total organization planning, the programmes introduced under its auspices run the risk of being harmful to the individual, organization and the economy. The skills being developed must be useful, challenging and not subject to rapid obsolescence and displacement. Manpower planning systems include several specific inter-related activities: ${ }^{14}$

\section{Manpower inventories}

Manpower inventories are used to assess current resources and their present level of utilization. The information contained in a manpower inventory enables the firm to match the skills in the organization against gross manpower requirements. Having a manpower inventory is also essential to intelligent participation in total corporate planning. It provides the input for advice concerning the capability of the organization to undertake projects and for estimating the cost of acquiring additional manpower capabilities. Firms that fail to consider the manpower implications of acquisitions have found that they did not have the managerial, technical or operative manpower capability to exploit the opportunities presented by acquisitions.

\section{Forecasts of manpower supply and demand}

'Intelligence about the supply and demand of manpower at a given time and place can and often does affect the timing of corporate investments." ${ }^{\text {s }}$

Availability or lack of availability of skills may influence the location of facilities, and will provide planners with some indication of the lead time available to manpower administration in the acquisition of required manpower.

\section{Manpower programmes}

Such programming permits, on a totally integrated basis, the design and implementation of action programmes to ensure that the manpower needs of the organization are met over time. These programmes entail all of the traditional personnel functions - but the emphasis here is on the acquisition, maintenance and development of manpower skills. Thus the functions of recruitment, selection, placement and training receive prime consideration. Training and development is pivotal and interacts with manpower utilization by enlarging the labour supply by means of

- raising the skills of the work force;

- increasing versatility and adaptability;

- increasing productivity. ${ }^{16}$

\section{Control and evaluation procedures}

These procedures provide feedback to the manpower planning system and monitor the degree of attainment of man- power goals and objectives. Such procedures are essential for organization-wide success in achieving manpower goals and will not occur through disjointed functional efforts. One of the most important functions of control and evaluation is to guide the manpower planning activities through time, identifying the causes of deviations from the plan. Fundamental to the control and evaluation process are goals and objectives to serve as yardsticks in measuring performance. Difficulty in establishing adequate and accurate criteria in no sense nullifies the manpower planner's rexponsibility to evaluate.

Such a systematic approach to manpower planning allows the enterprise to be proactive rather than reactive and to manage the future effectively.

Inherent in this model is the need for provision for interaction between the planners and the policy makers so that corporate goals, timing, availability of product, readiness and the availability of manpower can interact with economic and market forecasts, facilities, investment plans and thus provide the basis for establishing manpower requirements. A manpower planning operation can, therefore, consist of a sequence of corporate policy, corporate planning and manpower requirements and forecasts; utilization of the workforce and the developing of it to meet both current and future needs. Such a model will assist in making decisions with regard to whether the organization should train present manpower or acquire the necessary skills from external sources. In addition, it allows for the translation of requirements into budgets and goals for the organization.

Specificity of plans will vary with the length of the planning period. In the first place, the planning period should provide the organization with adequate time to make necessary adjustments to potential problems and needs as revealed by the manpower forecast. And in the second place, the length of the planning activities within the organization. Integration and co-ordination of future plans is required in order to ensure overall planning effectiveness.

The strength of taking a longer-range approach on a total organizational basis is that needs, particularly changing requirements, are anticipated in advance and they can be met at minimum (optimum) costs to the organization and maximum benefit to the individual.

Ultimate success in manpower planning is dependent on

- the calibre of the action programmes established to achieve manpower objectives;

- the ability of the organization to implement these programmes;

- the quality of the data bases used to produce the manpower inventory and the forecasts of manpower supply and demand;

- (perhaps most importantly) the degree of integration of manpower planning with other planning activities within the organization.

The relationship between strategy, structure and human resource management ${ }^{17}$

Strategy can be defined as the process through which the basic missions and objectives of the organization are set. It includes the process through which the organization utilizes its resources in order to achieve its objectives. The 
structure of an organization can be seen as embodying the fundamental division of labour. It also describes the nature of jobs and aggregates them into groups/functions. The structure of an organization follows from its strategy.

Human resource management should be added to the strategic arena, focusing on such issues as fitting performance measures to strategy; structure (organizational design); rewards, career pathing and leadership styles. The fundamental problem of strategic management lies in keeping strategy, structure and human resource dimensions of the organization in direct allignment.

'There is something to be gained through systematically matching strategy, structure and human resource management. At best, such matching gives both human satisfaction and effective organizational performance.' 18

In the past human resource management has been largely missing from the general strategic management arena and if the organization is to function effectively, human resource management should be included as an integral part of the strategic arena of the organization.

\section{The study}

\section{Scope and method of investigation}

This study hoped to establish if Personnel Managers participate in corporate strategy formation especially from the human resources point of view. The image of the personnel manager in major companies was generally speaking bad, playing a minor role in the policy decisions in the firm. The hypothesis of this study was: in the 1980's the personnel manager will become a part of the top management team of companies because human resource management is a vital part of the corporate strategy of the firm. Thus, this hypothesis was tested in this study. More specifically, the objectives of this study were:

- to establish if Personnel Managers were part of the top management team;

- to establish the extent of their participation in the corporate planning process;

- to establish if there is any interrelationship between Human Resource Management and Corporate Strategy.

A questionnaire was drawn up and all respondents were to be interviewed personally. The respondent in all cases was the head of the personnel department in a company listed on the Johannesburg Stock Exchange. The head of the Personnel department was the Personnel Director in some cases, the Personnel Manager in other cases and the Human Resource Manager in others.

Sixty firms were chosen, ten each from the following sectors listed on the JSE: Financial; Insurance; Mining; Paper and Packaging; Construction and Industrial.

The Companies were chosen at random using judgemental sampling. The author believes that sixty companies is a representative sample from the above-mentioned sectors. A larger sample would not have made any material difference to the results of this survey.

The fieldwork was undertaken in November 1982 by trained post-graduate students. ${ }^{19}$ The completed questionnaires were then checked, analysed, and the findings tabulated. The results of the survey are presented below:
Table 1 The personnel manager as part of the top management team

\begin{tabular}{ccc}
\hline & No. & $\%$ \\
\hline Yes & 50 & 83 \\
No & 10 & 17 \\
\hline Total & 60 & 100 \\
\hline
\end{tabular}

The majority of companies in the sample ( 83 per cent) said that the head of personnel was on the top management team. This indicates an acceptance of the importance of the personnel function. It would appear that in the seventeen per cent not incorporating the personnel manager in the top management team, that the personnel specialist is seen as academic, theoretical, inexperienced and detached from the management.

Table 2 The personnel managers participation in corporate strategy formation

\begin{tabular}{ccc}
\hline & No. & $\%$ \\
\hline Yes & 50 & 83 \\
No & 10 & 17 \\
\hline Total & 60 & 100 \\
\hline
\end{tabular}

All personnel managers who are in the top management team (87 per cent of the sample), participate in the corporate strategy formation of their companies. This indicates that personnel managers who are on the executive team of their company are responsible for certain policy decisions that will influence strategy formation for the company as a whole.

Table 3 How the personnel manager participates in corporate strategy formation

\begin{tabular}{lrr}
\hline & No. & $\%$ \\
\hline Formal meetings with the general manager & 47 & 78 \\
Informal meetings with the general manager & 42 & 70 \\
Written reports to the general manager & 37 & 62 \\
At management meetings & 35 & 58 \\
Other & 5 & 8 \\
\hline
\end{tabular}

Most heads of personnel participate in corporate strategy formation through formal meetings as well as informal meetings with the general manager. Written reports and management meetings also play a role.

Almost all participation in corporate strategy formation by personnel managers was restricted mainly to obviously related personnel functions such as: the company's mentality and image, the company's performance and goals, and political and social factors. Those elements of corporate 
Table 4 Aspects of corporate strategy that personnel managers participate in

\begin{tabular}{lcc}
\hline & No. & $\%$ \\
\hline The width and depth of products & 12 & 20 \\
Degree of vertical integration & 17 & 28 \\
Geographic coverage & 29 & 48 \\
The choice of competitive weapons & 15 & 25 \\
The company's mentality and image & 45 & 75 \\
The company's performance and goals & 45 & 75 \\
Political factors & 44 & 73 \\
Social factors & 46 & 77 \\
Economic factors & 37 & 62 \\
Market factors & 23 & 38 \\
Product and technological factors & 12 & 20 \\
Competitive factors & 24 & 40 \\
\hline
\end{tabular}

strategy that seem at first unrelated to personnel, for e.g. product and technology which both have a bearing on training, retrenchment and recruitment seemed to receive restricted attention.

Table 5 Do personnel managers make predictive judgements about the future?

\begin{tabular}{ccc}
\hline & No. & $\%$ \\
\hline Yes & 51 & 85 \\
No & 9 & 15 \\
\hline Tolal & 60 & 100 \\
\hline
\end{tabular}

Eighty-five per cent of the personnel managers interviewed claim to assist the general manager in making predictive judgements about the future. All of them qualified their claims by indicating that decisions were made purely on personnel related matters such as training needs, manpower planning, industrial relations, organization structure and skills inventories.

Table 6 Resources evaluated by the personnel manager in conjunction with the general manager

\begin{tabular}{lcc}
\hline & No. & $\%$ \\
\hline Human resources & 58 & 97 \\
Financial resources & 15 & 25 \\
Management resources & 49 & 82 \\
Operational resources & 17 & 28 \\
\hline
\end{tabular}

Ninety-seven per cent of the personnel managers said that they evaluate human resources and eighty-two per cent stated that they evaluated management resources. This finding is as expected. Only 25 per cent were involved in evaluating financial resources. This seems strange because the personnel manager will have to be involved in the per-
Table 7 Does the general manager consult the per. sonnel manager with regard to strategic alternatives?

\begin{tabular}{ccc} 
& No. & $\%$ \\
\hline Yes & 39 & 65 \\
No & 21 & 35 \\
\hline Total & 60 & 100 \\
\hline
\end{tabular}

sonnel budget. Only 28 per cent were involved in operational resources. This has a bearing on the personnel function if for example the company becomes capital intensive and has to lay off workers.

Sixty-five per cent of the personnel managers claimed that they were consulted by the general manager with regard to the strategic alternatives facing the company in the future. However, it appears that this was done from the human resource perspective, for example, with vertical integration, the personnel manager participates in the decision only in so far as it affects the labour complement.

Table 8 Does the personnel manager advise the general manager on the organizational structure of the firm?

\begin{tabular}{ccc} 
& No. & $\%$ \\
\hline Yes & 56 & 93 \\
No & 4 & 7 \\
\hline Total & 60 & 100 \\
\hline
\end{tabular}

Ninety-three per cent of the personnel managers claimed that they were involved in advising the general manager on the organizational structure of the firm. Although this in itself is a good sign, the degree to which they are involved in this advisory capacity, probably differs from individual to individual. Furthermore, the amount of advice actually accepted will depend on the personality of the general manager and of the personnel manager.

Table 9 Responsibility for the identification of middle and top management in the firm

\begin{tabular}{lrr}
\hline & No. & $\%$ \\
\hline General manager & 7 & 12 \\
Personnel manager & 14 & 23 \\
Both & 39 & 65 \\
\hline Total & 60 & 100 \\
\hline
\end{tabular}

Both the general manager and the personnel manager are responsible for the identification of middle and top management potential in the firm. This is the correct way of handling this matter. 


\section{Conclusion}

It would be true to say in general that the personnel manager is involved in the formulation of corporate strategy in the majority of companies in the sample. The degree of involvement was not absolute. The personnel manager only participated in areas traditionally associated with personnel.

The personnel policies of a company depict its basic human resources philosophy and reflect its belief system with regard to people. In some companies people are merely one resource amongst an array. Companies using an approach based on such a philosophy tend to operate with fairly restrictive personnel policies. At the opposite end of the continuum are those companies which view their personnel as their most vital resource. Such companies tend towards personnel policies which are focussed on improving human performance. It appears that top management is beginning to appreciate the extent to which the human resource element is one of the few growth resources within the company structure; most other assets depreciate. Since human resource management has a major impact on industrial performance and hence on productivity and organizational performance it is imperative that the organization ensure that its corporate strategy is such that it provides scope for the growth and development of the personnel within the organization. It is those companies who support and complement the concept of strategic planning for the people of the organization in conjunction with the other resources, who can be seen to be concerned with long term, pro-active corporate policy making.

\section{References}

1. Ackoff, R.L. A Concept of Corporate Planning, New York: John Wiley and Sons, Inc., 1970, p.1.

2. Jun, J. et al. Tomorrow's Organizations, Glenview, Illinois: Scout Firesman and Co., 1973, p.165.

3. Schendel, D.E. et al., Strategic Management. Boston: Little Brown and Company, 1979, p.265.

4. Likert, R. The Human Organization, New York: McGraw-Hill, 1967, p.123.

5. For instance, conflict would occur if personnel programmes were not in line with the technical requirements of production, and the collection of confidential data would be impossible if departments were not instructed by higher managernent to reveal this information to authoriz ed planners.

6. Filley, A. et al., Managerial Process and Organizational behaviour, Glenview, illinois: Scott Firesman and Co., 1969, p.191.

7. Personnel Departments should have information retating to the following areas:

Desigration of key positions in the organization

- incumbents;

- potential replacements;

Salary schedules;

Evaluation/appraisal results: Work force information

- separation rates and absenteeism statistics;

- skitts inventory;

- recruiting: sources, costs and time required;

- job designations and wage rates;

- ratio of personnel staff to work force;

- information concerning union-management relations and future predictions in this area:

- employee services and benefits.

8. For example, alleviating crash hiring and training programmes in relation to production booms and skimps, costs can be lowered and com. pany atmosphere and morale greally improved.

9. Bennis, W. et. at. The Planning of Change, New York: Holt, Rinehart and Winston, 1961, p.260.

10. Skinner, W. 'Big hat, no cattle: Managing Human Resources', in Harv. Bus. Rev. September-October, 1980, p.114.

11. Ewing, D.W. 'Corporate Planning at Crossroads,' in Harv. Bus. Rev. July - August, 1967, p.38.

12. Staffing may be regarded as 'optimum' when at the right moment, the organization is provided with an acceptable number and type of persons who are both able and willing to do the necessary work.

13. Cassell, F. 'Manpower Administration: A new role in Corporate Management,' in Warman, M.S. et al. Emerging Concepts in Management, New York: MacMillan, 1975, p.170.

14. See amongst others: Newton, D. 'Manpower Planning,' in Margerison, C., et al. Planning for Human Resources, London: Longmans Green and Co., 1974

15. Ibid., p. 170.

16. Ibid., p. 171.

17. See amongst others: Tickey, N.M. 'Strategic Human Resource Management,' in Sloan managem. Rev. Winter, 1982.

18. Schendel, D.E. et al. op. cit.. p. 265.

19. The author wishes to thank the 1982 post graduate Higher Diploma in Personnel Management class for participating in the fieldwork. 